\title{
SOCIOLOGICAL ASPECTS OF THE CINEMA
}

$\mathrm{T}$ HE sociological and psychological importance of the film was under review in four papers at the first meeting of the Psychology Section of the British Association at Dundee on August 31. The discussion ranged from the film tastes of the adult to the uses that could be made of the film in the classroom, and in this connexion the question was raised whether sufficient attention is being given to the possible uses of the cinema apart from entertainment.

Knowledge of its manifold uses is so meagro that a suggestion was put forward for the creation of a Cinema Research Institute with an income of $£ 50,000$ a year. The objects of such an institute would be to co-ordinate to their mutual advantage the conflicting viewpoints of the various sections of the trade; to equate the demands of the public with the financial, technical and artistic resources of the industry, and lastly to use modern methods to discover the uses to which films could be put in the service of the modern democratic and world community. Its work would also be of value to Government: Departments, official and semi-official bodies, municipal authorities, transport concerns, advertisers, social workers, and last but not least to the cinema industry. itself.

The first investigation which it was suggested should be carried out was a general market research. There has nover been any attempt to classify cinemagoers by age, sex or social categories. All that is known to-day is that the total number of regular cinema-goers in Great Britain in normal times is between 16 and 17 millions per week, with another 7 millions a week of more occasional visitors.

The second task a Cinema Research Institute should undertake is a research into the likes and dislikes of audiences by trained observers. The makers of films have certain 'hunches' that such and such a film will be a success, but the intuition is based on empirical calculations alone. Such an investigation would also doubtless show that the motives for attendance at the cinema are various. There are those who go to the 'pictures' for escape; the suburban housewife, for example, or the clerk or the manual worker slaving away at a monotonous job. There are, too, the courting couples who have no more interest in the pictures on the screen than in the man in the moon and to whom the comfort and isolation of the cinema is infinitely preferable to the chill of the city streets or the hardwood chairs and continuous interruptions of their own homes. Then there are those who go for an evening of good family entertainment on a regular day each week.

None of these groups is highly critical of the content of the films which they see. On the other hand, since receipts from films vary considerably, there must be a large but unknown number of people who pick and choose their film entertainment. Some go to see a particular star; others to see a dramatization of a play or a novel of which they have heard and which they think they will enjoy upon the film. Others go because their friends say that it is a good picture. Others because they have seen a good review in the 'fan' press or enjoyed the 'trailer' shown the week before. Lastly, there are the few who go to the films because they are interested in films as an art form similar to the theatre or music.

The last line of research that ought to be immediately undertaken is one into the film sociological and psychological effects. What, for example, will be the effect in international relations and political thought of the new tendency of the American filmmakers to inject political propaganda into the films now being put upon the public sereen? How far should the film be used for domestic government propaganda? The documentary or realist films sponsored by great interests like gas, oil or the General Post Office, are cases in point. "Housing Problems" directs attention to the need for better houses ; "Enough to Eat" to problems of nutrition; "The Londoners" to the system and importance of local government; "Men in Danger" to industrial disease; or the American-mado film "The River" to the Tennessee Valley Authority's work.

Nevertheless, in some respects all films have propagandist effect. The young peoplo of to-rlay aro better turned out than they used to be, and homes aro more comfortable, all because of the effect of the film. Where one should draw the line between conscious and unconscious attempts to influence the filmgoer, is a question yet to be resolved. So far as the British public is concerned, direct propaganda rarely succeeds unless it is camouflaged as 'interest'.

The 'interest film' is capable of much further development. Both adults and children will stand for a great deal of education provided that it is not too obvious. Almost any pill will be swallowed if nicely coated with jam! Whero so many amateur organizers of children's matinées go wrong, is that they bore their audiences and hence the experiment is unsuccessful. The professional children's matinée such as is run by some 700 picture houses in Great Britain is entertainment pure and simple. It consists of a good action film or serial, a cartoon sufficiently simple for children to understand, and an interest short film and a comedy. Dr. Inglis, of the University of Glasgow, made a plea for the film, which he said is not nearly so bad as it is painted, for it gives the children a love of adventure and a sense of beauty. It certainly has no effect on juvenile crime. In fact, closing these theatres would be likely to lead to an increase in anti-social conduct.

Side by side with the use of the film as children's entertainment runs the use of the film as one of the optical aids for children's instruction. Its value as a teaching aid has been abundantly proved. Films enable children to retain facts longer, open up the wider world around the child and, last but not least, instruct them in citizenship.

The reception given to this year's discussion emboldens one to suggest that the cinema is worthy of more than a sectional discussion and the committee might well consider if next year it should not form a topic for one of the evening lectures, perhaps under the auspices of the Division for the Social and International Relations of Science.

Oliver Berl. 